\title{
Mateusz Skucha
}

Uniwersytet Jagielloński

\section{Emancypanci i ich emancypator}

\author{
O książce Macieja Dudy Emancypanci \\ i emancypatorzy. Mężczyźni wspierajacy \\ emancypacje Polek $w$ drugiej połowie XIX \\ i na początku XX wieku
}

\section{Abstract \\ Emancipationists and Their Emancipator}

The article discusses Maciej Duda's book Emancypanci i emancypatorzy. Mężczyźni wspierajacy emancypacje Polek $w$ drugiej połowie XIX $i$ na poczatku XX wieku [The Men that Supported the Emancipation of Polish Women in the Second Half of the $19^{\text {th }}$ and Early $20^{\text {th }}$ Centuries]. In the introduction, some issues that can be problematic for a researcher examining the history of men who supported pro-feminist movements are pointed out (difficulties with naming, resistance of feminists, number of publicists). Next, the composition and methodology used by the author, as well as main areas of the research are discussed and some critical comments are voiced. Finally, a conclusion is drawn that the book is a valuable publication as it fills the gap in Polish research on the history of feminism.

Słowa kluczowe: Maciej Duda, feminizm, emancypacja, kobieta, mężczyzna, emancypant, emancypator

Keywords: Maciej Duda, feminism, emancipation, woman, man, emancipationist, emancipator 
W roku 1992 ukazała się monumentalna antologia Against the Tide. ProFeminist Men in the United States, 1776-1990 opracowana przez Michaela Kimmela i Thomasa Mosmillera. Autorzy rozpoczynają książkę od anegdoty:

Kiedy powiedzieliśmy naszym feministycznym przyjaciółkom i koleżankom, że przygotowujemy antologię dokumentującą historię mężczyzn wspierających ruch kobiet w Stanach Zjednoczonych, niektóre były zaskoczone. „Mężczyźni, którzy wspierali feminizm?” - zapytała jedna. „To z pewnością będzie najkrótsza książka w historii!"’.

Nic bardziej mylnego. Antologia liczy ponad 500 stron i zbiera wypowiedzi blisko 150 profeministów, deklarujących poparcie dla ruchu sufrażystek, emancypantek i feministek. Okazuje się więc, że mężczyźni włączali się w prorównościowe działania kobiet w XIX i XX wieku. Chociaż zauważyć trzeba, że kwestia „feministów” jest problematyczna. Już samo określenie „feminista" wywołuje wątpliwości. W haśle Męski feminizm wyjaśniam rzecz następująco:

Nazwa „feminista” jest w języku polskim zwyczajowa, stosuje się także takie określenia, jak: mężczyzna profeministyczny, prorównościowy, antydyskryminacyjny, antyseksistowski. Feminiści anglojęzyczni nazywają siebie profeminist male, ponieważ sądzą, że określenie się jako feminist (z ang. feministka, feminista) wiązałoby się z zagarnięciem nazewnictwa emancypujących się kobiet, a tym samym z zawłaszczeniem tradycji i historii dwustuletniej walki o równouprawnienie $^{2}$.

Inna sprawa to stosunek feministek do mężczyzn i ich obecności w ruchu feministycznym. Na przykład Rosi Braidotti stwierdza kategorycznie:

Nie ma i nie powinno być dla mężczyzn miejsca $\mathrm{w}$ feminizmie: przestrzeń feministyczna nie należy do nich i nie powinni jej oglądać [...]. Na myśl o całej klasie (kaście) mężczyzn, którzy są zafascynowani, zaciekawieni czy onieśmieleni widokiem używającej pióra kobiecej inteligencji feministycznego rodzaju, budzi się we mnie rodzaj zniecierpliwienia ${ }^{3}$.

${ }^{1}$ Against the Tide. Pro-Feminist Men in the United States, 1776-1990: A Dokumentary History, eds. M.S. Kimmel, T.E. Mosmiller, Boston 1992, s. XIX. Tłum. moje - M.S.

2 M. Skucha, Męski feminizm, [hasło w:] Encyklopedia gender. Pteć w kulturze, red. M. Rudaś-Grodzka et al., Warszawa 2014, s. 311.

${ }^{3}$ R. Braidotti, Podmioty nomadyczne. Ucieleśnienie i różnica seksualna w feminizmie współczesnym, przeł. A. Derra, Warszawa 2009, s. 167. 
Zdecydowana większość feministek ma odmienne zdanie, na co wskazuje chociażby następująca wypowiedź Toril Moi:

Nie lubię określenia „mężczyźni w feminizmie” (men in feminism). To amerykanizm. Brzmi to jakby feminizm był miejscem, do którego mężczyźni wchodzą. Jakoś mi się to nie podoba. Sądzę, że mężczyźni powinni być przeciwnikami patriarchatu. Jeśli traktują poważnie takie pojęcia jak wolność, sprawiedliwość czy prawa człowieka, to wręcz muszą być wrogami patriarchatu. Myślę, że mężczyzna, który nie jest przeciwnikiem patriarchatu, nie ma nic na swoje usprawiedliwienie. Nie toczę więc bojów z tymi, którzy angażują się po stronie feminizmu. Szczerze ich popieram ${ }^{4}$.

Dodatkowo należy wziąć pod uwagę liczbę publikacji autorstwa zwolenników emancypacji, co już w 1873 roku na łamach „Przeglądu Tygodniowego” odnotowywał Aleksander Świętochowski:

Literatura sprawy niewieściej w ostatnich kilku latach rozmnożyła się u nas wyraźnie. [...] Przypatrując się tym traktatom, widzimy w nich jeszcze pewną powierzchowność sądu, sentymentalne reminiscencje, ubóstwo argumentów, kosmopolityzm nieuwzględniający potrzeb i warunków miejscowych, ale widzimy także wybitny postęp przekonań. [...] W dwu latach ostatnich szpargałów takich [tj. dotyczących tzw. kwestii kobiecej - dop. M.S.] pojawiło się mnóstwo. Kto tylko kochał choć jedną kobietę, a znał choć kilka, zaraz czuł się powołanym i uzdolnionym do układania praw dla połowy rodzaju ludzkiego. Poczciwe matki i ojcowie, emeryci, wyrostki, strapione marzycielki, tępi filolodzy, matematycy, słowem wszyscy, którzy nie mogli uszczęśliwić świata innym ekstraktem swego mózgu, uszczęśliwiali go elukubracjami w kwestii niewieściej. Przedmiot ten stał się najpożądańszą rolą dla wszelkich debiutów autorskich, najlepszym materiałem dla zabawki sił starganych lub z natury słabych. Każdy bowiem, kto jeszcze, już, albo nigdy myśleć i pisać nie umiał, myślał i pisał o kobietach. Stąd to powstały owe: Stowa, Kilka stów, Nieco i tym podobne efemerydy motylego istnienia. Z początku ogół zaciekawiony sprawą chwytał te świstki - wkrótce jednak zrażony stałą nicością wielu, omijał następne. [...] Bo podług naszego zdania płody te nie przynosiły żadnej korzyści umysłowej, a fatalnie szargały sprawę, która dla swego rozjaśnienia wymagała pracy obszernej i wyczerpującej . $^{5}$

Ten krótki przegląd cytatów i zagadnień niewątpliwie świadczy o tym, jak nie lada wyzwaniem byłoby napisanie historii polskich zwolenników

${ }^{4}$ Feminizm jest polityczny. Z Toril Moi rozmawia Matgorzata Walicka-Hueckel, ,Teksty Drugie" 1993, nr 4-6, s. 112.

5 A. Świętochowski, Przegląd piśmiennictwa polskiego, „Przegląd Tygodniowy” 1873, nr 6, s. 44 . 
emancypacji kobiet. Do tej pory kwestia ta nie została gruntownie zbadana ${ }^{6}$. Piszę „do tej pory”, bo właśnie (w 2017 roku) ukazała się obszerna monografia Macieja Dudy pod tytułem Emancypanci i emancypatorzy opatrzona podtytułem Mężczyźni wspierajacy emancypację Polek $w$ drugiej połowie XIX i na poczatku XX wieku. Od razu powiedzieć trzeba, że książka jest znakomita, nie tylko dlatego, iż onieśmiela ogromem zgromadzonego materiału, lecz także dlatego, iż napisana jest ze swadą i zaangażowaniem, dzięki czemu czyta się ją z zainteresowaniem i niekłamaną przyjemnością.

Autor zdaje sobie sprawę z problemów, o których pisałem wyżej. Stąd wiele uwagi poświęca samej idei „bycia feministą” i często ważniejszy staje się dla niego gest postawienia pytania niż udzielenia odpowiedzi:

Czy mężczyzna może być także podmiotem, nie tylko przedmiotem badań feministycznych, czy męski feminizm to oksymoron, czy pragnienie mężczyzny, by być podmiotem dyskursu feministycznego, nie jest chęcią podstępu, skolonizowania ostatniego terytorium, na którym nie ma głosu (s. 24);

albo: „co oznaczało bycie emancypantem lub emancypatorem? Kim byli emancypanci i emancypatorzy? Jaka była ich motywacja? Jakie zyski i straty ponosili, współpracując z emancypantkami i organizacjami kobiecymi?" (s. 35). Tym samym Duda ujawnia pewną samoświadomość, dotyczącą przede wszystkim miejsca, jakie zajmuje $\mathrm{w}$ dyskursie, czy też pozycji, z jakiej opowiada dzieje XIX-wiecznych emancypantów. Tę samoświadomość potwierdził już w swojej wcześniejszej książce pod tytułem Dogmat płci. Polska wojna z gender (2016), w której uważnie śledził spory wokół kategorii gender zainicjowane przez mylne jej odczytanie prezentowane przez Kościół katolicki. Z kolei na łamach miesięcznika „Znak” w wywiadzie przeprowadzonym przez Monikę Świerkosz wyznawał:

Dla mnie szczególnie istotne jest to, że tamtym mężczyznom, podobnie jak mnie dzisiaj, chodziło o holistyczny projekt zmiany strukturalnej, przekształcenie mechanizmów społecznych i polityki, tzn. o znacznie szersze ujęcie, o łączenie spraw kobiet i mężczyzn, o społeczną odpowiedzialność za nas wszystkich ${ }^{8}$.

${ }^{6}$ Do wyjątków należą tu: artykuł Małgorzaty Fuszary o Ludwiku Krzywickim, szkic Ewy Kraskowskiej o Juliuszu Kadenie-Bandrowskim oraz kilka moich tekstów poświęconych rozmaitym dyskursom profeministów w XIX w. Marginalnie wzmiankowały o tym: Grażyna Borkowska, Aneta Górnicka-Boratyńska i Sławomira Walczewska (choć ta ostatnia całą kwestię - delikatnie rzecz ujmując - upraszczała).

${ }^{7}$ M. Duda, Emancypanci i emancypatorzy. Mężczyźni wspierający emancypację Polek $w$ drugiej polowie XIX i na początku XX wieku, Szczecin 2017. Wszystkie cytaty pochodzą $\mathrm{z}$ tego wydania, w nawiasach podaję numery stron.

${ }^{8}$ Sukienka, która (nie) straszy. Maciej Duda w rozmowie z Monika Świerkosz, „Znak” 2015, nr 725, s. 21. 
Widać zatem wyraźnie swego rodzaju nadrzędny zamysł książki: autorowi chodzi z jednej strony o zrekonstruowanie dziejów polskich emancypantów, z drugiej - o odzyskanie pewnego ważnego wątku w historii mężczyzn, a dzięki temu o nowe spojrzenie na mężczyzn w Polsce w XXI wieku.

Wyjaśnienia wymaga tytuł. Autor słusznie zrezygnował z anglosaskiego określenia „profeminiści” oraz polskiego „feminiści”; zdecydowały o tym „względy historyczne, nie ideowe” (s. 32). Wybrał natomiast słowa funkcjonujące w XIX wieku, odnotowane w Stowniku języka polskiego Jana Karłowicza, Adama Kryńskiego i Władysława Niedźwiedzkiego: emancypant „Zwolennik emancypacji kobiet” i emancypator - „krzewiciel emancypacji, oswobodziciel. Torował drogę, po której mieli stąpać przyszli emancypatorowie" (s. 32). To wybór trafny, ponieważ pozostaje w zgodzie z tendencjami epoki (stosowanie słowa „feminizm” byłoby tu anachronizmem, jako że sam wyraz pojawia się pod dopiero koniec stulecia), a także dlatego, że nie kryje się tu żaden gest zawłaszczający dokonania emancypantek. Nawet jeśli mężczyzna popiera emancypację (czy później - feminizm), zajmuje inną pozycję w dyskursie niż kobieta, bo ma inne doświadczenie opresji, o czym przekonująco pisał Jacques Derrida w Ostrogach.

Innym problemem, z jakim musiał się zmierzyć Duda, była ogromna liczba ówczesnych publikacji na ten temat. Jak sam wyznaje: „Moim zamiarem nie jest skonstruowanie tabeli, w której w odpowiedniej rubryce wybranym symbolem można zaznaczyć poparcie lub jego brak dla wpisanego w nią zakresu reform" (s. 35). Zauważa zresztą, że nie dałoby się tego zrobić, m.in. ze względu na rozpiętość czasową (1842-1918), obszar trzech zaborów, czynniki gospodarcze i klasowe (pochodzenie emancypantów) oraz dynamikę wprowadzanych reform. Dlatego też, pisze Duda:

Konstruując pracę o emancypantach i emancypatorach, korzystam z porządku, który obejmuje problemowy oraz kontekstowy opis zagadnienia. Nie utrzymuję ścisłego porządku chronologicznego. Porządek wyznacza następstwo zmian i reform, nie następstwo twórców i tekstów (s. 63).

Zabieg ten przyniósł znakomite rezultaty, bo dzięki tak obranej optyce uzyskujemy pewnego rodzaju mapę problemową, obejmującą m.in. wspieranie kobiet najpierw w edukacji, ekonomii, prawie i sferze obyczajów, w końcu kwestie (auto)biograficzne i (auto)definicyjne.

Jednym z najbardziej interesujących fragmentów jest rozdział pierwszy, najobszerniejszy, który pomyślany został nie tylko jako klasyczny wstęp (zawierający opis metodologii, stanu badań i układu), ale także jako tekst będący możliwie najszerszą prezentacją omawianego zjawiska. Pojawiają się tu setki nazwisk, pogrupowanych według różnych kryteriów, dziesiątki czasopism, mnóstwo publikacji i rozmaitych instytucji. $Z$ braku miejsca nie podaję przykładów, ale reprezentatywne są m.in. strony 38-41. Rzecz jasna, rozdział ten 
ma charakter bardziej sprawozdawczy niż interpretacyjny, co w tym wypadku nie jest zarzutem. Ujawnia bowiem z całą mocą rozległą wiedzę autora, a także pogłębioną świadomość rozmaitych uwikłań i zależności. Przecież innego typu argumentację zastosuje socjalista, a innego demokratyczny liberał; inną biolog, a inną prawnik; jeszcze inną mieszkaniec zaboru rosyjskiego czy Galicji itd.

Zresztą podobną sumację zastosował Duda w zakończeniu książki. Tutaj jednak klasyfikacja przebiegała wedle autorskich kategorii:

[...] istotnych cech wyłaniających się z pism i działań opisanych mężczyzn nie da się złożyć w jednowymiarowy obraz, w konkluzywną całość. Ich zbiór jest niestabilny i sprzeczny. Wśród czynników wyznaczających obraz mężczyzn wspierających kobiety walczące o emancypację znalazły się [...] tyrania Krzywickiego i Radlińskiego, rywalizacja Świętochowskiego i Krzywickiego, dżentelmeństwo Kelles-Krauza, kategoria fizycznej czystości wyraźna u Dybowskiego i Kelles-Krauza, kategoria odpowiedzialności za krzywdę innych charakterystyczna dla pism Kijewskiego i Kelles-Krauza, kategoria altruizmu przedstawionego jako cecha społecznika u Świętochowskiego albo jako cecha kobieca u Dybowskiego, kategoria psychicznej indywidualności ponad płcią, która kształtowała projekty Chmielowskiego i Dybowskiego, kategoria honoru istotna dla Starczewskiego, kategoria rycerskości wyznaczająca projekty Prądzyńskiego, kategoria hierarchiczności budująca relacje wyżej cenionej kobiecości i mniej zorganizowanej męskości u Dybowskiego, mizoginia cechująca Popiela, wreszcie kategoria relacyjności i równorzędności wobec żony, partnerki u większości opisywanych oraz partnerskiej indywidualności najwyraźniej zarysowanej w listach Kelles-Krauza (s. 390-391).

W kolejnych rozdziałach autor snuje opowieść o rozmaitych zjawiskach i różnych osobach związanych z emancypacją kobiet w XIX wieku. Opowiada o Entuzjastkach i Entuzjastach (redaktorach Edwardzie Dembowskim i Hipolicie Skimborowiczu), o wychowaniu (jak Piotr Chmielowski czytał teksty Klementyny z Tańskich Hoffmanowej), o edukacji w ujęciu Aleksandra Świętochowskiego, o wyższym wykształceniu kobiet (zwłaszcza o zawodzie lekarki), o kwestiach ekonomicznych i obyczajowych (m.in. o emancypacji zarobkowej i o prostytucji), w końcu - o obywatelskich prawach i obowiązkach kobiet (szczególnie działalność Edwarda Prądzyńskiego i Leona Petrażyckiego). Ostatnie dwa rozdziały mają inny charakter, ponieważ pojawia się w nich zagadnienie sposobu prowadzenia dyskusji (pewnych strategii retorycznych i erystycznych) oraz sprawa (auto)biografii emancypantów (np. interesująca interpretacja pamiętnika Odona Bujwida). Podkreślić trzeba, że liczba omawianych rozpraw nie ogranicza się do tych kilku nazwisk. Autor analizuje kilkadziesiąt publikacji napisanych zazwyczaj przez osoby zupełnie dziś zapomniane. Tym cenniejszy jest zabieg umieszczania w przypisach not biograficznych. Nie zaburza to samej lektury, a zarazem stanowi ważny kontekst oraz źródło informacji. 
Książka Dudy z całą pewnością zasługuje na uznanie, wypełnia bowiem istotną lukę w badaniach nad historią polskiego feminizmu. Kilka kwestii budzi jednak zastrzeżenia. W rozdziale poświęconym pisarzom sympatyzującym z emancypantkami autor skupia się na postaciach Józefa Ignacego Kraszewskiego oraz Bolesława Prusa, choć przecież stosunek obu panów do emancypacji nie był jednoznaczny i oczywisty, pomija natomiast Teodora Tomasza Jeża, który napisał kilka powieści o emancypantkach (Emancypowana, Nauczycielka, Wyśnione, Jaskótki). Duda wspomina również Wacława Nałkowskiego, ale jedynie jako autora mało istotnego Pamiętnika uczonej kobiety. A przecież Nałkowski ogłosił dwie inne ważne rozprawy: Sienkiewicziana (w której krytykuje Sienkiewicza za sposób ukazywania kobiet) oraz Nie tędy droga, szanowny panie! (ostra w tonie polemika z mizoginiczną broszurą Karola Niedziałkowskiego Nie tędy droga, Szanowne Panie!). Szkoda też, że autor nie ulokował działalności polskich emancypantów na tle podobnych inicjatyw podejmowanych w innych krajach Europy i w Stanach Zjednoczonych. Owszem, wspomina o Angielskiej Lidze Mężczyzn oraz jej polskim odpowiedniku, ale jedynie krótko wzmiankuje o Międzynarodowej Lidze Mężczyzn dla Praw Wyborczych Kobiet, nie odwołując się do konkretów. Innym pominiętym kontekstem jest działalność Czechów (takich postaci jak Vojtěch Náprstek czy Tomáš Garrigue Masaryk). Są to oczywiście raczej sugestie i podpowiedzi aniżeli zarzuty, tym bardziej że dałoby się zapewne wskazać więcej podobnych osób.

$\mathrm{Z}$ kolei największe moje wątpliwości budzi ten fragment zakończenia, w którym autor próbuje spojrzeć na „męskość emancypantów” (s. 387) przez pryzmat współczesnych teorii. Zarówno kategoria „lepkiej męskości” (Kalle Berggren), jak i „męskości inkluzywnej” (Eric Anderson) są tutaj co najmniej dyskusyjne. Nie mówiąc już o tekście Patricka Califii Męskości, gdzie w gruncie rzeczy wszystko zostaje sprowadzone do testosteronu, który autor musi przyjmować po tranzycji. Wskazanie tego eseju jest o tyle nieuzasadnione, że Duda zaraz później wyznaje: „Califia pisał z pozycji współczesnego, myślącego niebinarnie mężczyzny, który urodził się w ciele kobiety. Jego myśl nie jest tym samym, co projekt człowieczeństwa emancypantów" (s. 392). Zakończenie zyskałoby, gdyby autor pokazał raczej „ciągi dalsze” działań XIX-wiecznych emancypantów, to znaczy naszkicował późniejszy przebieg procesów przez nich zapoczątkowanych.

$\mathrm{Na}$ koniec chcę wspomnieć o trzech największych zaletach rozprawy Dudy. Po pierwsze, autor nie tylko odnajduje kolejne teksty emancypantów i je omawia, lecz także prezentuje dyskusje wokół nich, polemiki, recenzje czy recepcje, co sprawia, że książka staje się dynamiczna, by tak rzec - żywa i żywiołowa. Po drugie, Dudę cechuje umiejętność cytowania reprezentatywnych fragmentów pism emancypantów, a następnie opatrywania ich błyskotliwym komentarzem. Podam jeden przykład. Po przytoczeniu fragmentu książki Piotra Chmielowskiego Kobiety Mickiewicza, Stowackiego i Krasińskiego, autor interpretuje go tak: 
Czytany współcześnie wstęp Chmielowskiego brzmi podobnie do prób wyjaśnienia czegoś, co w polskim tłumaczeniu nazywa się płcią społeczno-kulturową. W tym ujęciu słowa opublikowane w 1893 roku brzmią rewolucyjnie. Autor utrzymywał, że poza różnicą fizjologiczną nie ma istotowych różnic między obywatelami i obywatelkami (s. 103).

Takich i podobnych ustępów jest oczywiście znacznie więcej. Po trzecie, w książce Dudy drobiazgowe, misterne interpretacje nieustannie przeplatają się z wnioskami natury ogólnej. Ta zasada indukcji przyniosła znakomite efekty. Przykładem jest chociażby taki fragment:

Lektura pism kolejnych emancypantów wyznacza perspektywę inną niż uniwersalistyczna. Można założyć, że sądy panów wspierających emancypację kobiet wynikały nie z idei klasycznego liberalizmu, jednak argumentacja zawarta w ich pismach odsyła do innego konceptualizowania różnicy, a nie do jej zniesienia [...]. Prawa obywatelek miały być prawami partykularnego państwa narodowego. Przede wszystkim miały służyć odbudowie narodowej państwowości. Toteż idee głoszone przez emancypantów bliższe były założeniom feminizmu relacyjnego niż feminizmu indywidualistycznego (s. 279-280).

Wszystko to sprawia, że książkę czyta się z prawdziwą przyjemnością. $Z$ jednej bowiem strony Duda oddaje głos swoim bohaterom, z drugiej - wyraźnie zaznacza własne zdanie. Tym samym otrzymujemy fascynującą, niejako podwójną opowieść o emancypantach w XIX wieku i o współczesnym autorze - feminiście?, profeminiście?, emancypancie?, emancypatorze? który próbuje odzyskiwać swoją męską, kobiecocentryczną genealogię.

\section{Bibliografia}

Against the Tide. Pro-Feminist Men in the United States, 1776-1990: A Dokumentary History, eds. M.S. Kimmel, T.E. Mosmiller, Boston 1992.

Anderson E., Teoria męskości inkluzywnej, przeł. P. Sobolczyk, „Teksty Drugie” 2015, $\mathrm{nr} 2$.

Berggren K., Lepka męskość. Poststrukturalizm, fenomenologia i podmiotowość w krytycznych studiach nad męskościa, przeł. W. Śmieja, „Teksty Drugie” 2015, nr 2.

Borkowska G., Cudzoziemki. Studia o polskiej prozie kobiet, Warszawa 1996.

Braidotti R., Podmioty nomadyczne. Ucieleśnienie i różnica seksualna $w$ feminizmie współczesnym, przeł. A. Derra, Warszawa 2009.

Califia P., Męskości, przeł M.A. Pelczar [w:] Teorie wywrotowe. Antologia przektadów, red. A. Gajewska, Poznań 2012. 
Chmielowski P., Kobiety Mickiewicza, Stowackiego, Krasińskiego. Zarys literacki, Warszawa 1886.

Derrida J., Ostrogi. Style Nietzschego, przeł. B. Banasiak, Gdańsk 1997.

Duda M., Emancypanci i emancypatorzy. Mężczyźni wspierający emancypację Polek $w$ drugiej połowie XIX i na poczatku XX wieku, Szczecin 2017.

Feminizm jest polityczny. Z Toril Moi rozmawia Małgorzata Walicka-Hueckel, „Teksty Drugie" 1993, nr 4-6.

Fuszara M., Niekonsekwentny feminista czy niekonsekwentny antyfeminista? Krzywicki jako badacz społecznej i ekonomicznej sytuacji kobiet [w:] Wizjoner i realista. Szkice o Ludwiku Krzywickim, red. J. Hrynkiewicz, Warszawa 2012.

Górnicka-Boratyńska A., Stańmy się sobq. Cztery projekty emancypacji (1863-1939), Izabelin 2001.

Kraskowska E., Juliusza Kadena-Bandrowskiego walka o Nową Kobietę [w:] Lektury ptci. Polskie (kon)teksty, red. M. Dąbrowski, Warszawa 2008.

Skucha M., Adwokat sprawy niewieściej. $O$ dwóch cyklach artykułów Aleksandra Świętochowskiego w „Przeglądzie Tygodniowym” [w:] Pozytywiści warszawscy. „Przeglad Tygodniowy” 1866-1876, red. A. Janicka, Białystok 2015.

Skucha M., Benedykt Dybowski i Włodzimierz Popiel, albo o pewnym dyskursie profeministów polskich przełomu XIX i XX wieku, „Pamiętnik Literacki” 2016, nr 2.

Skucha M., Feminizm pozorny, albo jak mizogini walczyli o prawa kobiet, „Bibliotekarz Podlaski” 2015, nr 31.

Skucha M., Męski feminizm, [hasło w:] Encyklopedia gender. Płeć w kulturze, red. M. Rudaś-Grodzka et al., Warszawa 2014.

Skucha M., „,Niewieści Palladyn”. Rzecz o Edwardzie Prądzyńskim, „Autobiografia. Literatura. Kultura. Media" 2016, nr 1 (6).

Skucha M., Poczet feministów polskich XIX wieku [w:] Przemiany dyskursu emancypacyjnego. Seria I: Perspektywa środkowoeuropejska, red. A. Janicka, C. Fournier Kiss, M. Bracka, Białystok 2017.

Sukienka, która (nie) straszy. Maciej Duda w rozmowie z Monika Świerkosz, „Znak” 2015, nr 725.

Świętochowski A., Przegląd piśmiennictwa polskiego, „Przegląd Tygodniowy” 1873, nr 6.

Walczewska S., Damy, rycerze i feministki, Kobiecy dyskurs emancypacyjny w Polsce, Kraków 2000. 